\title{
11. James Bond and Art Cinema
}

\author{
Christopher Holliday
}

\begin{abstract}
The James Bond films are an enduring example of "escapist" popular cinema seemingly at odds with the filmmaking traditions of European modernism. However, this chapter offers the 007 film series as a candidate for Britain's contribution to the European Art Cinema tradition. From Maurice Binder's opening credits for Dr. No (1962), reminiscent of experimental filmmaker Len Lye, to the discontinuous editing patterns and jump cuts of $\mathrm{On} \mathrm{Her}$ Majesty's Secret Service (1969), 196os Bond cinema formally registers the violation of the classical norms and stylistic traits upon which art cinema was predicated. This chapter accordingly identifies how the stylistic transformation of the early Bond films can be woven into the art cinema traditions and political modernism of post-war European filmmaking.
\end{abstract}

Keywords: art cinema; European; style; modernism; British; James Bond

I'd just seen a very pretentious picture called L'année dernière à Marienbad, where everybody was wandering down moonlight paths with sculptures and Christ knows what, so we put Sean in there. - Terence Young, director of From Russia with Love (1963)

Part-Hitchcock and part-Hollywood in their "double" identities, the James Bond films express a shared occupancy within both the British imperial spy thriller and American blockbuster filmmaking traditions. However, the oo7 film series also counts among its multitude of push-pull relationships the adventure serial, film noir, the British New Wave, the B-movie, Italian comic books and pulp fiction, and 196os Eurospy cinema; a mixed pedigree that, when taken together, reveals the myriad of influences and afterlives that underscore the most commercially-successful film series in post-war

Verheul, J. (ed.), The Cultural Life ofJames Bond: Specters of oo7. Amsterdam: Amsterdam University Press, 2020 DOI 10.5117/9789462982185_CH11 
British cinema. Taking into consideration the multiple genealogies of Eon's official Bond films, this chapter introduces modernist - and particularly European-art cinema traditions as often overlooked points of intersection with 007 's big-screen adventures. Brian Hoyle $(2009,407)$ is not alone in asserting that "British cinema did not have an indigenous equivalent to the modernist European art cinema of countries such as France, Italy and Germany in the 196os and 1970s." However, despite the Bond series' status as an enduring example of "escapist" popular cinema seemingly at odds with the realisms, looser narratives and languid stylings of European modernism, this chapter offers the 007 films as a potential candidate for the presence of a British art cinema tradition. With particular focus on the striking narrative and formal elements of sixties Bond cinema that foregrounded "narrational acts" (Bordwell 2008, 155), this chapter identifies how the stylistic transformation of Bond cinema, in spite of its popularist appeal and pervasive "Britishness," can be productively woven into multiple art cinema traditions (British, European, and North American) and political modernisms of post-war filmmaking.

\section{The Specter of Europe}

The visible absence of a clear-cut art cinema tradition within British film has been a mainstay of its critical narrative, culminating in what Thomas Elsaesser $(2005,14)$ calls British cinema's "many false dawns as an art cinema." Despite several protestations - most notably by Peter Wollen (1993) and Alan Lovell (1997) — against traditions of British social realism as embodying a native art cinema in Britain, many scholars have suggested that an art cinema was able to develop through mid-century realist conventions just as it had done so in the concurrent national filmmaking traditions of the French Nouvelle Vague, Italian Neorealism and Young German cinemas. The naturalism and verisimilitude of "Free Cinema" and, later, the British New Wave with its "authentic" socially-purposive sentiments and political poeticism staked a strong claim to be considered Britain's contribution to a global art cinema. Although British cinema has typically been omitted from European-centric critical studies of auteurism, Britain "was at least intellectually at the very core of the domination of the European art cinema in the 1950s" (Hedling 2003, 23). While perhaps lacking a coherent set of figures to rival Ingmar Bergman, Federico Fellini, Roberto Rossellini and Luchino Visconti, it was filmmaker Lindsay Anderson and his co-founding of the Sequence film journal that propagated a radical British 
"art cinema credo" (Hedling 2003, 24). Sown in the pages of a specialist publication devoted to transmitting the individualism of the filmmaker (thereby anticipating French auteurism by several years), what might be termed British art cinema was intellectualized in the 1950s prior to the emergence of a distinguishable body of "socially-realist" films towards the end of the decade and into the sixties.

The prevailing assumption, however, has been that social realist traditions cannot quite be reconciled as the fullest realization of an indigenous art cinema in Britain. Hoyle (2009, 407-08) suggests that any notion of a "British" art cinema exists only sporadically in the work of filmmakers such as Anderson, Joseph Losey, Ken Russell and Nicolas Roeg (in addition to expatriates Michelangelo Antonioni and Roman Polanski), and ultimately did not achieve full coherency until the early 1980s through figures like Derek Jarman, Peter Greenaway, Peter Watkins, Terence Davies and Sally Potter. In the work of these later filmmakers, prior social realist traditions would merge more readily with European art cinema to form "social art cinema," in which social and political engagement was delivered more explicitly through strategies of formal hybridity and a self-conscious narrative style (Williams 1996; Hill 1999). This broader critical uneasiness around the legitimacy of "Free Cinema" and the British New Wave as art cinema movements further explains the consistent critical turn toward any separate "deviant, non-realist British cinema" (Street 1997, 188) as a way of qualifying the existence of a true British art cinema more in line with the aesthetic traditions, formal radicalism and political critique of post-war European cinema. Marked by the work of experimental animators Len Lye and Norman McLaren, the earlier 1920 and 1930 s period of British avant-garde practices has been credited with "nurturing a cultural appreciation for art cinema, particularly amongst the intelligentsia" (McFarlane 2016, 29). For Sarah Street (1997), it was the later formal experiments of filmmakers Michael Powell and Emeric Pressburger in the 1940s-at a time when continental art cinema was gesturing primarily towards a realist aesthetic — that ultimately served to push British domestic production towards a more conspicuously modernist style. Street $(1997,200)$ argues that Powell and Pressburger offered, under the guise of their production company The Archers, "exciting and significant contributions to the corpus of national cinemas," which constituted clear "aesthetic experiments" in the "commercial feature industry" of the United Kingdom. These were films that therefore rejected the naturalism of the British Documentary Movement of the late-1930s while anticipating the later, hardened period of modernist "art cinema" in Britain during the 1970s and 1980s. 
Whether paperback hero or big-screen British Intelligence agent, the figure of James Bond seems immediately incompatible with discussions of a "British interest in non-narrative experimental art cinema" (Street 1997, 188) in particular, and European art cinema more broadly. Circulating within the global market and firmly in the mainstream, the 007 film series is an international filmmaking phenomenon and an exemplar of post-war popular cinema. The series is far removed from "art cinema" as both an industrial and aesthetic category, not outwardly defined by the "modes and circuits of production, distribution and exhibition" (Neale 1981, 13), or the formal conventions (ambiguous endings, rejection of classical storytelling, "open" narratives) that traditionally position "art cinema" outside the mainstream Hollywood style. Beyond the divisions of high/low or art/commerce that normally structure categories of the popular, Bond films similarly operate at a distance from a specific kind of "authored" or auteur art cinema. Despite a regular coherency of British directors (Terence Young, Guy Hamilton, Lewis Gilbert and, later, John Glen), as Sinclair McKay $(2010,27)$ playfully put it, "being a director on a Bond film is not so much a job for an auteur as a circus ringmaster."

However, a closer examination of the Bond series illustrates that rather than enforce traditional dichotomies between "art" and "popular" filmmaking, or indeed classical and modernist cinemas, these two strands are more in dialogue with one another than is often assumed. This is because the Bond series occupies something of a missing link between two historical moments in British art cinema's chronology. The birth of the official series with $D r$. No (UK: Terence Young, 1962) comes towards the end of the early-196os British New Wave movement, but before the 1970 s and 1980 s when British cinema strayed from its naturalist style to consolidate a recognizable art film aesthetic cut to the pervasive European model. The 007 of these sixties' films was (to a degree) congruent with the anti-authoritarian "Angry Young Man" social type of the British New Wave (often played by regional actors), even if the Bond narratives themselves were outside the mold of "kitchen sink" realism that supported these Free Cinema successors. At the same time, there was certainly something about the 007 film series that marked them out as a radical break from contemporaneous British cinema of the period.

It was in their Modernist production design (typified by the work of Berlin-born Ken Adam) for their elaborately engineered set pieces that the Bond films eschewed the primacy of location shooting and levels of realism that became the hallmark of multiple New Wave and art cinema movements. The architectural splendor of Adam's set designs, including spacious command centers, cavernous control rooms and elaborate underground lairs 
evoking the mid-century architectural form of Frank Lloyd Wright, Albert Kahn, Pierre Koenig and Charles-Édouard Jeanneret, provided a suitable backdrop for the lofty aspirations of the Bond villains, if not a startling counterpoint to the moderate Georgian-style interior of oo7's home first glimpsed in Dr. No. It has also not been outside the remit of Bond villains to appropriate pre-existing modernist structures for their sinister operational bases. John Lautner's futuristic Elrod House and the minimalist Moroccan villa designed by Algerian architect Imad Rhamouni-a protégé of French designer Philippe Starck - were used by Ernst Stavro Blofeld in Diamonds Are Forever (UK: Guy Hamilton, 1971) and Spectre (UK/USA/Austria/Mexico/ Italy/Morocco:Sam Mendes, 2015), respectively, as a suitable accompaniment to his hyperbolic megalomania.

Modernist architecture certainly supports the identity of sixties Bond as a "colorful fantasy" (Chapman 2005, 9) that marked a wider shift within British film culture away from a fifties cinema committed to social realism. Yet the cleaving of 007 from British filmmaking of the period is often underscored by the series' degrees of attachment to popular American cinema. Filmmaker François Truffaut's criticisms of the 007 films (as nothing more than parodies of Hitchcock) bears out the dislocation of Bond from the social and political reality of post-war Europe through the character's anchorage in mainstream Hollywood culture. Truffaut argued that with 007 "mass audiences were exposed to what amounts as a degradation of the art of cinema" (quoted in Bergan 2008, 130). Bond thereby represented American "decadence," with an identity as a Hollywood product that betrayed Bond's presumed "Britishness" as defender of the Empire. At the same time, the Bond movies did trade in a strong(er) European flavor, bearing the stamp of a particular kind of European sensibility largely defined in opposition to the North American entertainment cinema.

Produced outside any recognizable studio system by American Albert "Cubby" Broccoli and Canadian Harry Saltzman for their London-based company Eon Productions, the 007 films were UK/US co-productions and trans-Atlantic products, aided by a distinctly European flavor from the outset. Tim Bergfelder $(2000,149)$ argues that 007 was "indebted to popular European genre traditions" more so than they were to contemporary American genres of the sixties period. The Bond films further "replicated the attractions of the European adventure film," bringing globe-trotting expanse, stunts and action together with "escapist pleasures" that offered a low-brow appeal to the European market. Elsaesser (2005: 47) suggests the Bond films should actually be considered "part of European cinema," aligning the series with a diverse range of more typically European post-war 
products, from the rural sentimentality of the Heimat films in Germany to the Italian Spaghetti Western. The strong intercontinental casting of the 1960 s Bond films also marked a concerted effort by Broccoli and Saltzman to target European audiences. Kim Newman argues $(1986,51)$ :

Although to many, the James Bond films represent the epitome of AngloAmerican movie-making, they were expressly aimed at a multi-national audience from very early on. The casting of guest stars from the German (Gert Fröbe, Lotte Lenya), French (Claudine Auger) and Italian (Ursula Andress, Daniela Bianchi, Adolfo Celi, Luciana Paluzzi) popular cinema did much to give the series an international feel. ${ }^{1}$

Despite Andress (Dr. No) and Auger (Thunderball [UK: Terence Young, 1965]) having their voices dubbed by English actresses, the presence of these foreign-born performers were "the perfect example of the type of woman the producers like to cast [...] in the early 007 thrillers-European, large-breasted, and very sexy" (Rubin 2002, 333). Many of these stars of the early Bond films inhabited European cinema both before and after their roles in the 007 series. Prior to Thunderball, for example, Auger (a runner-up in the 1958 Miss World contest) had featured in European auteur Jean Cocteau's The Testament of Orpheus (France: Jean Cocteau, 1960), and would remain predominantly a star in Europe. Indeed, with the spy film genre "among the high points of their careers," many former Bond Girls went "back to Italy, France or Germany for international films of dubious merit" (Lisanti and Paul 2002, 18-19). Once there, such starlets routinely featured in those European (commonly Italian) spy films that parodied the official 007 series. Andress and Auger appeared in Anyone Can Play (Italy: Luigi Zampa, 1968), Bianchi in O.K. Connery (a.k.a. Operation Kid Brother) (Italy: Alberto De Martino, 1967) and Shirley Eaton in the Germany/Spain/ US co-production The Girl from Rio (West Germany/Spain/USA: Jesús Franco, 1968), roles that developed the 007 mythology across the interstices of multiple national cinemas.

Supported by the casting of European females, perhaps the strongest identifier of the Bond series' Europeanness was ultimately their portrayal of sex, sexuality and erotic display. The risqué nature of the 007 films certainly had more in common with the frank sexual content of European art cinema of the period than it did with either the political and social economy of the British New Wave, or the conservative ideology of Hollywood 
still largely marshalled by the restrictions of the Hays Code. Sex would go on to solidify the presence of the 1970s British art cinema, just as the "graphic tendency" and bankable eroticism of the "sex kitten" would serve to distinguish European art cinema's striking violation of code-era Hollywood throughout the 1960s (Betz 2009, 42). But if the European (and, later, British) art cinema casualized images of sex in ways that blurred ideological distinctions with soft-core pornography, then similar charges were leveled at Bond films. Since spy author John le Carré first described Fleming's original novels as "cultural pornography," the status of the source material as an early form of mass-produced pornography, if not Bond's historical links to the publication of Playboy, have been well-documented (Hines 2018). However, the ideological vision of Britishness signified by Bond within (and for) American culture was complemented by particular views of sexual behavior. In spite of the character's patriotic conservatism and indelible Britishness, British audiences celebrated 007's masculine promiscuity and guiltless sexual authenticity as strongly "European" (Ginneken 2007, 159). If the modest naturalism of the British New Wave typically dressed its women "in a dressing gown" (to quote the title of J. Lee Thompson's 1957 feature film), then the durable image of the alluring Bond Girl is one tied to her traditional appearance in the bikini (Andress, Eaton, Auger and Mie Hama in You Only Live Twice [UK: Lewis Gilbert, 1967] all appear in swimsuits) as a way of defining the boundaries of female glamor. Even when considering the contemporaneous British sex films and bedroom farces of the late-196os/early-1970s — such as Mary Had a Little... (UK: Edward Buzzell, 1961), No Sex Please-We're British (UK: Cliff Owen, 1973) and the Confessions series (UK: Val Guest et al., 1974-77)— the Bond series still provides a stronger evocation of the lubricious and luxurious eroticism of art cinema that flourished in many European cinemas following break-up of the Hollywood studio system.

Unlike these British-shot comedies that presented sex as "eccentric, peculiar and ambiguous" (Conrich 1998, 93), Bond films glorified their sexual content through a more European image of the sex symbol. Chris Darke $(2003,440)$ explains that in the post-war European context, sex was highly bankable as "a sophisticated yet earthy sexuality was important in opening up foreign markets for European art cinema abroad." European art cinema's array of female sex symbols obtained their impact from a shared cultural capital as curvaceous, combining excessive and voluptuous physicality with an enigmatic psychology of character that remained erotically mysterious. The 1960s Bond films traded specifically on these constructions of the "sex kitten" and European starlet, most famously embodied by Brigitte Bardot 
and Sophia Loren, as well as Gina Lollobrigida and Silvana Mangano in Italy. The fact the role of Tracy Di Vicenzo in On Her Majesty's Secret Service (UK: Peter Hunt, 1969) was originally intended for both Bardot and Catherine Deneuve, star of Belle de Jour (France/Italy: Luis Buñuel, 1967) reflects the kinds of sexually "sophisticated" European femininity desired by Broccoli and Saltzman. A symptom of his assertive bachelorhood and a marker of his freedom from British class relations, Bond's sexual mobility was regularly matched to the sexually promiscuous image of the ultra-feminine European women, whose socially transgressive pre-marital romances became a strong current of post-war continental Europe. This entwining of male and female sexuality certainly allowed for more modern representations of gender. Fitting strongly the "sex goddess" type of European art cinema, Paluzzi in particular (as villainous Fiona Volpe in Thunderball) conveys a eroticized rebelliousness and "conspicuous nudity" that reprises the Bardot-inspired undressed image of "nude sunbathing, soaked dresses clinging to her body as she frolics in the surf" (Betz 2009, 122) made famous in And God Created Woman (France: Roger Vadim, 1956).

The often sensationalist promotional material for the sixties Bond films shored up the series' relationship to more European art cinema standards of sexual content. Designed by American illustrator Mitchell Hooks, Dr. No's poster campaign depicted Bond (listed as "gentleman spy") outnumbered four to one by his sexual conquests in the film, who are pictured in various states of undress. In the international posters for From Russia with Love (UK: Terence Young, 1963), this ratio is maintained. Bond is surrounded by lead Bond Girl Tatiana Romanova, as well as the two fighting girls Vida and Zora, and the unnamed belly dancer played by Leila Guirat. With artwork by Italian commercial artist Renato Fratini (who would also move between art and popular cinemas, designing the poster for Anderson's This Sporting Life [UK: Lindsay Anderson, 1963]), the US design of From Russia with Love's poster art is clearly intended to re-conjure the glamour of the European sex symbol, while also evoking pulp magazine covers. In 1972, United Artists re-released all seven Bond films across Europe under the banner of the "Viva James Bond Film Festival." Illustrator Yves Thos' new posters for this "Viva” campaign bear a striking resemblance to Bardot's Le Mépris (France/Italy: Jean-Luc Godard, 1963), including an unidentified blonde woman kneeling at the feet of 007 reminiscent of the buxom Bardot, and tap into an image of female sexual behavior that supported "the art and commerce of the art cinema" (Bordwell 2008, 153).

Le Mépris is a film that for Bordwell $(2008,153)$ "works on the very problem of erotic spectacle in the art cinema." Such a "problem" is wholly rooted in 
the new sexual realisms and liberal sexual politics of art cinema. Godard's antagonism towards the feminine sexuality of Camille Javal—played by Bardot-in Le Mépris (translated as "Contempt") both punishes abundant eroticism through Camille's climactic death, while simultaneously evoking the expendability of those transgressive "bad" women across the Bond franchise equally marked by liberal, even deviant sexualities, including Volpe in Thunderball and Helga Brandt in You Only Live Twice. Seduced by Bond and, consequently, diverted from their villainous allegiance, both Volpe and Brandt fit the sixties template of oversexed European siren, yet their elimination as adversaries almost immediately following an erotic encounter with 007 connects promiscuity to disposability (unlike the "Good" Bond Women, whose initial resistance and self-declared immunity to Bond's sexual advances are typically assuaged by the films' end).

These emergent points of contact and overlap between the James Bond films of the 196os and the category of modernist art cinema serves to muddy the art/popular binary that has (politically, culturally, institutionally) separated many European cinemas from the Hollywood system. In this way, Bond finds a natural companion in Hitchcock, a filmmaker with which the series shares "common ideological and cultural ground" (Chapman 2014, 154), as well as certain visual motifs and narrative patterns. So too the Bond films - alongside Hitchcock as a figure of joint British and North American sensitivity - can be equally understood as intersecting with a self-conscious and highly distinctive European style. Many of the sixties Bonds embraced the art cinema as a set of stylistic conventions, adopting several of the alternative formal practices flourishing across European film through the 1950 s and 1960 s that Hitchcock would himself adopt in "his attempts at a European-style art film" (Haeffner 2005, 99). Indeed, as the next section of this chapter examines, the first decade of Bond cinema (1962-1969) seemingly recalled the earlier British "art" cinema period of experimental animation, with a clear formal expressivity more in line with the modernist credentials of the British and even mid-century American avant-garde cinemas.

\section{Shaking and Stirring? Bond's Modern Style}

Notable among critical responses to the atmospheric pre-credits sequence that begins From Russia with Love was its alleged connections to an exemplar of post-war European art cinema, L'année dernière à Marienbad (France/ Italy: Alain Resnais, 1961). Many reviewers of From Russia with Love noted the 
striking parallels between villain Red Grant's pursuit of 007 in the grounds of a moonlit garden, and the geography and mood of Resnais' film (Gilliatt 1963; Bennett 1964). Penelope Houston (1964, 28) — who was the inaugural editor and co-founder of the Sequence film journal in Britain with Anderson and Reisz - wrote that Bond and Red Grant's "stalking match" (resulting in Bond's fake[d] death) takes place in the "formal gardens of a Marienbad chateau." The Marienbad reference would appear in another of Houston's reviews of the palatial setting in From Russia with Love for Monthly Film Bulletin in November 1963. However, Marienbad was not the only allusion to continental art cinema of the 1960 s to find its way into popular responses to Young's film. A review of From Russia with Love published in The Times on the October 10, 1963 suggested that its depiction of the Turkish capital Istanbul "set one wondering inevitably if this is what was really happening to the enigmatic heroine of L'Immortelle" (anon. 1963). ${ }^{2}$

Filmed on the evenings of April 16 and 17, 1963 at Pinewood's Renaissance garden, From Russia with Love's opening sequence is, for Chapman (2007, 76), a "deliberate reference to European Art cinema which establishes the very European style of the film." Flanked by Dr. No (Jamaica), Goldfinger (United States), Thunderball (the Bahamas) and You Only Live Twice (Japan), From Russia with Love is certainly the most European of all the sixties Bonds, taking in as part of its global expanse a variety of European cities-London, Istanbul, Belgrade and Venice-all networked together by the Orient Express that hosts the film's standout set piece. However, From Russia with Love balances references to art cinema with popular cinema, containing intertextual gestures to Marienbad and, more explicitly, Call Me Bwana (UK: Gordon Douglas, 1963) during the sequence in which SPECTRE agent Krilencu is shot by Kerim Bey while escaping through a billboard for the Broccoli-produced British comedy. Starring Anita Ekberg, who had herself become an international icon with art-house film La dolce vita (Italy/France: Federico Fellini, 1960), Call Me Bwana's presence in the second official Bond film narrativizes the series' vexed relationship to the popular. Hidden behind 007's façade of commercial cinema lies another, altogether more latent, identity of art cinema that prefigures the expatriate British filmmaking of the 1970s. Yet this duality does not void Bond's status as an exemplar of popular entertainment, but rather begins to place it in conjunction with the international profile of European art cinema.

2 L'Immortelle (France/Italy/Turkey: Alain Robbe-Grillet, 1963) director Alain Robbe-Grillet was a novelist and filmmaker, and as a key figure within cerebral art cinema collaborated (as screenwriter) with Resnais on Marienbad. 
Three of the next four Bond films released after From Russia with Love in the 1960s-Thunderball, You Only Live Twice and On Her Majesty's Secret Service - also make use of fragmented, discontinuous editing patterns and jump cuts, thereby formally registering something of European art cinema's violation of classical norms and stylistic traits. All edited by Peter Hunt, the climactic fight in Thunderball between Bond and Emilio Largo (Adolfo Celi) aboard the Disco Volante yacht, and the pre-credits sequence to $\mathrm{On}$ Her Majesty's Secret Service in which Bond disarms an assailant, present their violent action through frenetic editing patterns. In You Only Live Twice, however, jump cuts are used only briefly during the sequence in which autogyro Little Nellie is constructed by Q branch in front of Bond and a disbelieving Tiger Tanaka. Barry Langford $(2010,136)$ calls Hunt's radical use of such formal devices in the George Lazenby film as "unremarked jump cuts [...] [that] energize a violent fistfight," drawing parallels with the self-conscious fragmentation of time and space in the earlier $\grave{A}$ bout de souffle (France: Jean-Luc Godard, 1960). Most significantly, however, is Langford's (136) admission that the co-option of a European art cinema style by popular film (as represented here by Bond) marked the "mainstreaming of disruptive devices."

As a technique primarily the reserve of European modernist filmmaking, the jump cut has been widely theorized, typically in more conventional auteurist accounts of aesthetic meaning within the context of the French Nouvelle Vague. The intention of jump cuts was to destabilize the forward momentum of classical storytelling by disrupting the legibility of diegetic space and time. While anticipating the dizzying effect of intensified editing patterns in contemporary Hollywood action cinema, the fight sequences in both Thunderball and On Her Majesty's Secret Service upturn spatio-temporal coherency in ways that owe a debt to the stylistic repertoire of post-war French cinema. However, as Mark O'Connell (2012) notes, Hunt's editing patterns also evoked contemporaneous British art cinema of the period too, drawing from the "real/unreal stylings of British fare like Performance [UK: Nicolas Roeg, 1970], If... [UK: Lindsay Anderson, 1968] and Blow-Up [UK/USA/Italy: Michaelangelo Antonioni, 1966]," and exemplifying how the techniques of "Godard, Polanski, Bertolucci, Truffaut and Antonioni" were all "filtered down" into sixties Bond cinema. From a rhetorical use of mise-en-scène and temporal ellipses to radical shifts in compositional principles via reflexivity and abstraction, the experimental register of the modernist generation of international art auteurs shattered the classical style and narrative arrangement underwriting popular cinema's formal grammar. The momentum and visibility of jump cuts in Thunderball, You 
Only Live Twice and On Her Majesty's Secret Service thus offer an explicit narrational act that similarly counterpoints the long-take naturalism of British social realism and Classical Hollywood via the formal vocabulary of European space-time continuity.

Just as one of the commonalities of European art cinema is the mirrored return of the look via direct address, which as Tom Brown $(2012,17)$ argues features in such films "more often at the end [...] than at any other point," the address of the Bond films has likewise always been rooted in discourses of looking. At its most declamatory, the opening gun barrel motif in which 007 is glimpsed through the interior of a .38 caliber weapon awards spectators a point-of-view shot, before Bond himself turns to "shoot" directly into the camera. The moving white iris is simultaneously a gun barrel, a bullet hole, a camera lens, a microdot and a human eye, but ultimately a constellation of gestures denoting the many ways of seeing and being seen. As a formal device, it functions as a visual rhyme to the traditional ending disclaimer that "James Bond Will Return" which, unusually, gestures to a particularly open-ended narrative while at the same time intensifying spectatorial engagement through an acknowledgement of our presence by the fiction. As Bordwell $(2008,156)$ notes of European art cinema, "With the open and arbitrary ending, the art film reasserts that ambiguity is the dominant principle of intelligibility." The "open" endings to Bond films through the promise of 007 's return functions against more classical restraint, marking out the Bond film's aesthetic distinctiveness. The disclaimer operates as another intriguing moment of self-reflexivity that (as with the opening gun-barrel motif) recurs across the series, not only evoking art cinema's predilection for the "pensive ending," but inviting a particular form of spectatorship rooted in the power of a deviation from classical narrative conclusion through the assurance of a connecting sequel.

As one of the series' key signifiers, and a strong point of connection with "Hitchcockian" modernism, the seductive formal arrangement of the Bond title sequences are fleeting spaces of radical possibility and bravura heterogeneity that further stress the Bond series' modernist credentials. In the hands of designers like Maurice Binder and Robert Brownjohn (who designed the Dr. No, From Russia to Love and Goldfinger credits sequences, respectively), alongside their (mostly North American) contemporaries Saul Bass, Richard Williams and Pablo Ferro, the 1950s emerged as a time of "major change for the title sequence" (Stanitzek 2009, 54). With an increased turn towards metaphor and symbolism, Binder's 007 titles were a space where spatial montage and typography in motion provided a graphic match to the thrills, exoticism and affluence of oo7's big-screen adventures. 
Designed by Binder and animated by Trevor Bond (who began his career at the British cartoon film studio W.M. Larkins specializing in abstract modernist form), Dr. No is the first - and until Casino Royale (UK/Czech Republic/USA/Germany/Bahamas: Martin Campbell, 2006) the only-Bond film to segue directly from the gun barrel motif into the opening bars of the title song, in this case Monty Norman's arrangement of the James Bond Theme. Playing over Dr. No's gun barrel are a series of electronic pulses and a xylophone refrain. In the style of the experimental technique of musical composition known as musique concrète, Dr. No is the only film in the series to use such an abstract sound arrangement. The piece was allegedly composed by electronic musician Daphne Oram in July 1962 (three months before $D r$. No's October release) and titled "Atoms in Space." Dr. No frequently returns to electronic audio effects, notably in the soundtrack that accompanies oo7's escape from his cell in the eponymous villain's futuristic lair, which have been attributed to Oram's Oramics system (a machine that translated drawings made on glass slides into sound effects). Later Bond films would further mine the variance of auditory experience. The disjunctive editing patterns in $\mathrm{On}$ Her Majesty's Secret Service are similarly matched to a remarkably dissonant soundtrack. John Barry's score for the film was the first by a major studio to incorporate a Moog synthesizer in what was a "daring" and "groundbreaking application of electronic music" (Burlingame 2012, 85). Developed by New York-born engineer Robert Arthur Moog in the mid-196os, the Moog was a voltage-controlled synthesizer system that utilized "oscillators, keyboards, filters and modulators to generate unusual musical sounds" (84). The sonic possibilities of Oram's techniques and the Moog system showcased in Dr. No and On Her Majesty's Secret Service suggests the modernist credentials of several early Bond films extend to their soundscapes, musical techniques and acoustic effects, just as the wide-ranging impact of European modernism was to be found in North American product design, graphic design, commercial advertising and architecture.

Featuring minimalist graphic animation and the rhythmical movement of multi-colored dots, the title sequence for Dr. No remains largely atypical of the series insofar as it utilizes visually abstract circles of variant scale, size and geometry of forms. The animation of colored dots evokes artist Roy Lichtenstein's popular Ben-Day printing process (a visual hallmark of the Pop Art movement), though Binder's more abstract visual design for Dr. No would gradually cede to the image of the female body. Within the context of British national cinema, Chapman $(2007,63)$ notes that through its "kaleidoscope of brightly colored dots which flash on and off in rapid succession," Dr. No "is at pains to distance itself from the sober, restrained visual style which was 
so prevalent in British cinema, especially through its insistence on color." But if the Pop Art-style design of Bond's debut situated the film outside the kitchen-sink realism of British cinema of the period, it simultaneously aligned Binder's work with both the pictorial modernism of European avant-garde traditions and the earlier period of 1920 and 1930 B British art cinema.

The designer of fourteen credits sequences for Bond films between 1962 and 1989 (as well as several 007 trailers), Binder was a "ceaseless experimenterwith color (emulsions, filters), optical effects, underwater shots, slow motion, animation, electronic movement, superimposition and ways to blend or overlap images" (Kirkham 1995, 12). His titles were ingenuous surrealist collages, replete with moving typography, abstract imagery, and graphic colors that entwined humor with exotic sexuality, most obviously embodied in the silhouetted female nudes that became a staple of the series' highly-gendered discourse. Given his exploratory testing of composite imagery, distorting graphics, multi-images and fluid typography, it comes as little surprise that Binder's name regularly appears next to eminent experimental animation pioneers like Lye, Norman McLaren and Oskar Fischinger in wider histories of animated typographies, motion design and musical visualization (Betancourt 2016).

In his treatment of abstract motion, image overlaying and pictorial fluidity in Dr. No and his next film Thunderball, Binder can be further connected to the innovative, non-objective "absolute film" tradition of 1920 sermany anchored to the work of Fischinger, Walter Ruttmann, Viking Eggeling and Hans Richter. Taken together as forms of experimental animation, Binder's 007 titles are no less examples of what Fischinger himself termed "absolute color work, born quite of music" (quoted in Leslie 2002, 189), insofar as they trade in colorful, abstract and erotic imagery with a strong emphasis on rhythm and tempo. Fischinger's 1933 film Kreise (Germany: Oskar Fischinger, 1933; translated as "Circles"), for example, involves a remarkably similar molecular movement of colored dots synchronized to rousing orchestral music. One of the very first color films to be produced in Europe, and manufactured using the new Gasparcolor process (founded a year earlier by the Hungarian chemist Bela Gaspar), the notational pulsations in Fischinger's two-minute Kreise finds a corollary in Binder's beating circles that would begin the titles for Dr. No. Set to Franz Liszt's Second Hungarian Rhapsody, Fischinger's later film An Optical Poem (Germany: Oskar Fischinger, 1938) also experimented with the excessive and sporadic behavior of red dots fluctuating in size and scale, while Len Lye's A Colour Box (UK: Len Lye, 1935) made two years after Kreise also involves abstract colored circles and vertical lines as part of its visual patterning. McLaren's 1940 film Dots (Canada: Norman McLaren, 1940), which was produced by the animator scratching and painting directly 
onto the film strip, offers a further analogue to Binder's sequences that are no less a psychedelic experimentation with color and movement.

However, it is another of Lye's films, Rainbow Dance (UK: Len Lye, 1936), also made at the General Post Office that seems an obvious comparison to Dr. No, and connects Binder more directly to these historical traditions of British art cinema. With music by Filiberto Rico's Cuban-inspired Creole Band, Rainbow Dance is an abstract color advertisement produced once more with the Gasparcolor film stock, which in its striking design of silhouetted human forms parallels the middle section of Binder's titles for Dr. No. During the Bond film's opening title sequence, the design shifts from the multitude of flashing circles to the silhouettes of female dancers in red, purple, green and blue, who rhythmically gyrate to a calypso drum-beat. Each anonymous figure is layered over one another in a dizzying visual dance of overlapping colors. The psychedelic silhouettes of (often nude) female bodies engaged in a form of seductive striptease would become an icon of Binder's eroticized 007 titles. These female silhouettes in motion (signifying Bond-as-womanizer and international playboy) in $\mathrm{Dr}$. No, coupled with the formal experimentation of the preceding "dot dance," suggests multiple points of comparison with the contemporary (typo)graphic design of experimental animation in both Britain and across Europe.

Complementing the modernism of Ken Adam's bravura set designs, the abstract patterns of Binder's title sequences for the Bond series and his synchronization of sound and image would certainly not have looked out of place in a 196os period in which Lye and McLaren were still making experimental shorts. The non-narrative flavor of Binder's 007 title sequences suggests a shared lineage with the "absolute film" tradition popularized across Central Europe, but also American counterculture that would borrow its practices. Indeed, Kirkham $(1995,11)$ acknowledges the historical connections between Dr. No's titles and the "mind-blowing light, sound and multi-media shows [that] were spreading from the USA to Europe at this time." Binder's use of cutting-edge laser effects drew from this vibrancy of modernist moving image culture in sixties America, including liquid light shows accompanying avant-garde theater performances, holograms and laser installations.

Beyond the excitement of irregular "flashing dots and lights" (Kirkham 1995, 11) in Dr. No, Brownjohn's subsequent title sequences for From Russia with Love and Goldfinger provide further connections between 007 and continental art cinema. Brownjohn was strongly indebted in his visual style to Fischinger, but equally to the light filming projections of Hungarian László Moholy-Nagy, who had screened Fischinger's work to the Bauhaus art school in late-1920s Germany. In fact, Brownjohn was a protégé of Moholy-Nagy, 
under whom he studied painting and design throughout the forties at the Illinois Institute of Technology (formerly the New Bauhaus and founded by Moholy-Nagy in 1937), having previously been taught by German graphic designer Will Burtin at New York's Pratt Institute. Influenced by Soviet constructivist cinema, Moholy-Nagy's manipulation of light (he invented the Light-Space Modulator lighting equipment in 1930) and his experimental testing of light displayed onto clouds at the IIT Institute of Design are recalled in the title sequences for both the second and third Bond films. Beams of colorful light and film footage are projected by Brownjohn directly onto the female body-as-screen, positioned midway between the scandal of a peepshow parlor and light projection body art. ${ }^{3}$ Well-versed in the formal logic of European modernism and the potential for filmic abstraction, both Binder and Brownjohn therefore provide something of a connective between mid-century American avant-garde film, European art cinema practices and British cinema of the 1960 s. A closer look at the design of their undulating titles sequence ultimately illustrates the extent to which 1960 s Bond cinema evidently reflected back the audiovisual language of rhythm in light popular across European and North American art cinemas.

\section{Conclusion}

The received narrative of British cinema is one that has regularly outlined its compromise position between a Hollywood style and the cultural standing of Europe's art cinema. For Christopher Williams $(1996,193)$, it is a national cinema "caught between" these two alternatives, "unconfident of its own identity, unable to commit or develop strongly in either direction." Against the backdrop of Hollywood as a cinematic institution and post-war European cinema, the James Bond film series offers the study of British national cinema a new birthright, rather than a false dawn. This chapter has reconsidered the place of the James Bond films in relation to the formation of (popular) British national cinema, and suggested they function as something of a blind spot within the many possibilities and potentials of British, European and North American art cinemas. The genesis of the 007 film series in the 1960 , if not Bond's cultural currency as a popular hero, can certainly be connected to the liberation of the "Swinging" period, which would surrender as Bond

3 Emily King $(2005,204)$ argues that Brownjohn's erotic titles for From Russia with Love in which colored light is projected onto a belly dancer's body is "an extremely open-ended and positively experimental piece of film." 
entered into the 1970s and its new cultural and ideological terrain. But as very much a post-war film series, Bond cinema's popular appeal potentially obfuscates a discussion of their (at times) radical form and visual style. The sixties' Bond films are remarkably heterogeneous, not yet shaped by the weight of New Hollywood and its most popular genres, whether the emergence of Blaxploitation (Live and Let Die [UK: Guy Hamilton, 1973]) and science-fiction (Moonraker [UK/France: Lewis Gilbert, 1979], or the increased international visibility of martial arts and kung-fu cinema (The Man With the Golden Gun [UK: Guy Hamilton, 1974]) that would define the Roger Moore-era.

The distinct qualities of the early sixties' Bonds therefore lie in their own chronological place between the wave of socially-realist films in the $1950 \mathrm{os}$ and 1970 s British social art cinema. Terence Young's admission that he had watched L'année dernière à Marienbad, and his subsequent desire to "put Sean in there," certainly points to the possibility that European art cinema directly influenced the conceptualization and production of big-screen Bond. Given Binder and Brownjohn's further associations with American and European print artists and graphic designers, alongside connections to British animation and European modernism, it also seems likely that the boldly ambitious title sequence designs were envisioned to recall the modern European graphic aesthetic. Despite their exemplary standing as examples of popular filmmaking and their enjoyment by mass audiences, the early-196os Bond films are ultimately rich case studies within which it is possible to trace many historical and cultural waves of British art cinema, and similar streams manifest across Europe and North America, while smoothing over the persistent duality between art and popular cinemas. So as the history of Bond cinema continues to evolve and the franchise extends beyond its fiftieth anniversary, it might be in the recesses of European modernism that this most enduring example of British film harbors something of its own secret identity.

\section{Works Cited}

Anon. 1963. "Four Just Men Rolled into One." The Times, October 10, n.pag. Bennett, Colin. 1964. "Thrills and Tricks." The Age, April 23, n.pag.

Bergan, Ronald, ed. 2008. François Truffaut: Interviews. Jackson: University Press of Mississippi.

Bergfelder, Tim. 200o. "The Nation Vanishes: European Co-Productions and Popular Genre Formula in the 1950 and 196os." In Cinema and Nation, edited by Mette Hjort and Scott Mackenzie, 139-52. London: Routledge. 
Betancourt, Michael. 2016. Beyond Spatial Montage: Windowing, Or the Cinematic Displacement of Time, Motion, and Space. London: Routledge.

Betz, Mark. 2009. Beyond the Subtitle: Remapping European Art Cinema. Minneapolis: University of Minnesota Press.

Bordwell, David. 2008. Poetics of Cinema. New York: Routledge.

Brown, Tom. 2012. Breaking the Fourth Wall: Direct Address in the Cinema. Edinburgh: Edinburgh University Press.

Burlingame, Jon. 2012. The Music ofJames Bond. New York: Oxford University Press. Chapman, James. 2005. Past and Present: National Identity and the British Historical Film. London: I.B. Tauris.

Chapman, James. 2007. Licensed to Thrill: A Cultural History of the James Bond Films. London: I.B. Tauris.

Chapman, James. 2014. "Hitchcock and Bond." Hitchcock Annual 19: 153-80.

Conrich, Ian. 1998. "Forgotten Cinema: The British Style of Sexploitation.” Journal of Popular British Cinema 1, no. 1: 87-100.

Darke, Chris. 2003. “The French New Wave." In An Introduction to Film Studies Third Edition, edited by Jill Nelmes, 421-50. London: Routledge.

Elsaesser, Thomas. 2005. European Cinema: Face to Face with Hollywood. Amsterdam: Amsterdam University Press.

Gilliatt, Penelope. 1963. "Laughing it off with Bond." The Observer, October 13, n.pag. Ginneken, Jaap van. 2007. Screening Difference: Screening Difference: How Hollywood's Blockbuster Films Imagine Race, Ethnicity, Culture. Lanham: Rowman and Littlefield Publishers, Inc.

Haeffner, Nicholas. 2005. Alfred Hitchcock. London: Routledge.

Hedling, Erik. 2003. "Lindsay Anderson: Sequence, and the Rise of Auteurism." In British Cinema in the 1950s: An Art in Peacetime, edited by Ian MacKillop and Neil Sinyard, 23-31. Manchester: Manchester University Press.

Hill, John. 1999. British Cinema in the 1980s: Issues and Themes. Oxford: Clarendon Press. Hines, Claire. 2018. The Playboy and James Bond: oo7, Ian Fleming, and Playboy Magazine. Manchester: Manchester University Press.

Houston, Penelope. 1963. "From Russia with Love." Monthly Film Bulletin 30, no. 358: 155.

Houston, Penelope. 1964. "Whose Crisis?" Sight and Sound 33, no. 1 (Winter): 26-28, 50. Hoyle, Brian. 2009. "Radio On and British Art Cinema." Journal of British Cinema and Television 6, no. 3 (December): 407-23.

King, Emily. 2005. Robert Brownjohn: Sex and Typography. London: Laurence King Publishing.

Kirkham, Pat. 1995. “Dots and Sickles." Sight and Sound 5 (December):10-13.

Langford, Barry. 2010. Post-Classical Hollywood: Film Industry, Style and Ideology since 1945. Edinburgh: Edinburgh University Press. 
Leslie, Esther. 2002. Hollywood Flatlands: Animation, Critical Theory and the Avantgarde. London: Verso.

Lisanti, Tom, and Louis Paul. 2002. Film Fatales: Women in Espionage Films and Television, 1962-1973. Jefferson, North Carolina: McFarland \& Company, Inc., Publishers.

Lovell, Alan. 1997. “The British Cinema: The Known Cinema?” In The British Cinema Book, edited by Robert Murphy, 235-43. London: BFI Publishing.

McFarlane, Brian, ed. 2016. The Encyclopedia of British Film, Fourth Edition. Manchester: Manchester University Press.

McKay, Sinclair. 2010. The Man with the Golden Touch:How The Bond Films Conquered the World. New York: The Overlook Press.

Neale, Steve. 1981. “Art Cinema as Institution." Screen 22, no. 1 (May): 11-40.

Newman, Kim. 1986. "Thirty Years in Another Town: The History of Italian Exploitation, Part II." Monthly Film Bulletin 53, no. 625 (February): 51-55.

O'Connell, Mark. 2012. Catching Bullets: Memoirs of a Bond Fan. Hampshire: Splendid Books.

Rubin, Steven Jay. 2002. The Complete James Bond Movie Encyclopaedia, Third Revised Edition. New York: McGraw-Hill.

Stanitzek, Georg. 2009. "Reading the Title Sequence (Vorspann, Générique)." Cinema Journal 48, no. 4 (Summer): 44-58.

Street, Sarah. 1997. British National Cinema. London: Routledge, 1997.

Williams, Christopher. 1996. "The Social Art Cinema: A Moment in the History of British Film and Television Culture." In Cinema: The Beginnings and the Future, edited by Christopher Williams, 190-200. London: University of Westminster Press.

Wollen, Peter. 1993. "The Last New Wave: Modernism in the British Films of the Thatcher Era." In British Cinema and Thatcherism: Fires Were Started, edited by Lester Friedman, 35-51. London: UCL Press.

\section{About the Author}

Christopher Holliday teaches Film Studies and Liberal Arts at King's College London, specializing in film genre, international film history and contemporary digital media. He has published widely on digital technology and computer animation, including work in Animation Practice, Process \& Production and animation: an interdisciplinary journal. He is the author of The Computer-Animated Film: Industry, Style and Genre (Edinburgh University Press, 2018), and co-editor of Fantasy/Animation: Connections Between Media, Mediums and Genres (Routledge, 2018) for Routledge's AFI 
Film Readers series that examines the historical, cultural and theoretical points of intersection between fantasy and animation. He has also published articles on the performance of British actors in contemporary US television drama, and on the James Bond film franchise. 